\section{Nigella sativa oil: A promising prospective antifungal agent in the manufacture of low-salt soft cheese}

Eman F. Abdel-Latif, ${ }^{1}$ Khaled A. Abbas, ${ }^{2}$

Hani S. Abdelmontaleb, ${ }^{2}$

Shaimaa M. Hamdy ${ }^{2}$

${ }^{1}$ Department of Food Hygiene and Control, Faculty of Veterinary Medicine, Cairo University, Giza; ${ }^{2}$ Dairy Department, Faculty of Agriculture, Fayoum University, Fayoum, Egypt

\section{Abstract}

The current work studied the in-vivo antifungal activity of Nigella sativa oil (NSO) in ultrafiltered low-salt soft cheese as a proposed replacement for the synthetic preservatives which become unacceptable by consumers. Four different concentrations of NSO were examined during the manufacture of the cheese $(0.3,0.5,1$, and $3 \%$ $\mathrm{w} / \mathrm{w})$. The effect of NSO supplementation was examined in 3 parallel lines; a ninepoint hedonic scale was used in the sensorial evaluation of soft cheese free of the fungal inoculum, the physicochemical properties of soft cheese were determined during storage as well as anti-fungal effects of different concentrations of NSO on inoculated cheese with different species of fungi: Candida albicans $\left(10^{4} \mathrm{cfu} / \mathrm{ml}\right)$ and Aspergillus parasiticus $\left(10^{2} \mathrm{cfu} / \mathrm{ml}\right)$ before coagulation. The Nigella sativa oil expressed an antifungal activity by using different levels of NSO which significantly reduced and inhibited the growth of the fungal counts (1.4 log cfu/g for Candida albicans and $2.30 \log \mathrm{cfu} / \mathrm{g}$ for Aspergillus parasiticus) started from $0.5 \%$ concentration of NSO on the 14th day of the storage. In addition, it exhibited different physicochemical properties of soft cheese depending on the level of used NSO. However, the Sensory evaluation of cheese samples revealed the acceptance of soft cheese samples with $0.3 \%$ and $0.5 \%$ of NSO.

\section{Introduction}

Low-salt soft cheese is considered one of the most highly marketed cheeses worldwide and frequently used by consumers due to its nutritional value and low salt content regarding health issues (Puvača et al., 2020). However, the higher moisture content and low salt making this type of cheese highly susceptible to rapid deterioration by spoilage microorganisms that shorten its shelf life as well as contamination with different pathogenic organisms to be harmful for human consumption (Oliveira et al., 2016). In manufacturing of soft cheese, milk is pasteurized to certain temperature with certain holding time to kill all pathogenic bacteria and then adjusted to a proper temperature to facilitate the manufacturing transactions. Its higher moisture content around $62-70 \%, \mathrm{pH}$ (above 5) and water activity (above 0.940) are the key factor related to its microbiological safety and entire quality (Trmčić et al., 2017). Several mold species could cause numerous deteriorates in soft cheese leading to undesirable flavor, secretion of mycotoxins and affecting the safety of this type of cheese that may belong to Aspergillus, Cladosporium, Penicillium, Mucor, Fusarium, Monilia, and Alternaria beside, different yeast species include Candida spp., Kluyveromyces marxianus, Yarrowia lipolytica, Pichia spp. Geothricum candidum and Debaryomyces hansenii (Khorshidian et al., 2018). On the other hand, consumer awareness has increased towards eating safe food free from synthetic additives and preservatives, the matter made a limitation for its use in cheese manufacture (Khosravi et al., 2011). Natural additives have become the best choice for preserving and enhancing the quality of cheese products instead of chemical and synthetic ones. Essential oils might be a promising agent for protection against such infections besides their biological and therapeutic effects. Many essential volatile oils are being used as antiseptic and antibacterial agents, reduce inflammation, and might be active against fungal infections (Kostadinović et al., 2016). The hydrophobic nature of essential oils helping the easy penetration of bacterial membrane to interfere with the transportation mechanisms of macromolecules in bacterial cells that causing cell inactivation (Goñi et al., 2009). However, essential oils exhibit inhibitory activity against Gram-positive bacteria mainly more than Gram-negative due to the lipopolysaccharides that present in the membrane of Gram-negative bacteria (Tehrani \& Sadeghi, 2015). Essential oils could also be used as flavorings in foods besides their role in increasing the shelf life of food products due to many active constituents such as volatile components, monoterpenes, sesquiterpene hydrocarbons, aldehydes, alcohols, esters and other nonvolatile constitutes include hydrocarbons, fatty acids, sterols, carotenoids, waxes, cumarines and flavonoids (Khorshidian et al., 2018).

Nigella sativa oil is an oil of black seeds also known as black seed oil. It is being renowned for its antibacterial, antifungal,
Correspondence: Hani S. Abdelmontaleb, Dairy Department, Faculty of Agriculture, Fayoum University, 63514 Fayoum, Egypt. E-mail: hsm00@fayoum.edu.eg

Key words: Nigella sativa oil, Antifungal effect, Low-salt cheese, Sensory evaluation.

Contributions: The authors contributed equally.

Conflict of interest: The authors declare no potential conflict of interest.

Funding: None.

Availability of data and materials: All the data have been presented within the manuscript.

Received for publication: 17 May 2021. Accepted for publication: 26 October 2021.

This work is licensed under a Creative Commons Attribution-NonCommercial 4.0 International License (CC BY-NC 4.0).

CCopyright: the Author(s), 2021

Licensee PAGEPress, Italy

Italian Journal of Food Safety 2021; 10:9862

doi:10.4081/ijfs.2021.9862

antioxidant, antidiabetic, gastroprotective, anti-inflammatory, anticancer, antihypertensive, therapeutic properties, and immune-enhancing effects of numerous pharmaceutical and active substances (Hassanien et al., 2014; Cakir et al., 2016; Çakır \& Çakmakçı 2018; Georgescu et al., 2019; Puvača et al., 2020). Most of the active substances present in volatile essential oils are in higher percentages in black seeds. These substances are phenolic compounds that have antimicrobial and antifungal properties. In addition to, its aromatic nature making it usable as flavoring foodstuffs (Puvača, 2018). The main components of Nigella sativa are thymoquinone, $p$-cymene, carvacrol, $t$-anethole, 4-terpineol, and longifoline (Hosseinzadeh et al., 2007). The inhibitory activity of Nigella sativa is mostly due to the existence of Thymoqinone TQ (2-isopropyl-5-methylbenzoquinone), $p$-cymene and carvacrol which interfere with the protein synthesis in bacterial cell (Kahsai, 2002; Chebli \& Hassani, 2014). It was also proven that Nigella sativa oil rich in essential fatty acids, linoleic and oleic acids, sterols, tocols, minerals, vitamins, and volatile compounds (Hassanien et al., 2014).

The antifungal activity of Nigella sativa oil has been studied extensively against a wide range of fungal strains in vitro. However, the available data regarding its 
efficacy in cheese is limited. Therefore, the aim of this work is to investigate the effect of Nigella sativa oil in low-salt soft cheese in conducting protection against spoilage fungi, as well as to detect their influence on consumer acceptability of cheese.

\section{Materials and methods}

Nigella sativa oil (NSO) was obtained from Alrehab Herbs Company, Fayoum, Egypt. Fungi strains of Candida albicans ATCC 10231 and Aspergillus parasiticus ATCC 28285 were kindly obtained from the Department of Microbiology, Faculty of Veterinary Medicine-Cairo University, Egypt. Ultrafiltered milk was supplied by the Dairy pilot plant in the Faculty of Agriculture, Fayoum University, Fayoum, Egypt. Powder rennet (CHY-MAX, 2280 IMCU/ml) from Chr-Hansen's Laboratories (Denmark) and diluted with sterilized distilled water to a standard rennet solution before use. Commercial pure fine grade salt was bought from Emisal Company, Fayoum, Egypt. While Calcium chloride (Food quality grade) was from EL-Nasr Company, Cairo, Egypt.

\section{Analysis of Nigella sativa oil}

The Fatty acid and sterol composition of Nigella sativa oil was analyzed according to the method used by (Ramadan et al., 2010), while the total phenolic compounds were determined according to the method used by (Hassanien et al., 2014).

\section{Preparation of inoculum}

The cultures (Candida albicans \& Aspergillus parasiticus) were activated with two successive passes in $9 \mathrm{ml}$ of SDB (Sabouraud Dextrose chloramphenicol broth, Oxoid) and incubate aerobically at $25^{\circ} \mathrm{C}$ for 3-5 days to have a final concentration of approximately $10^{4} \mathrm{cfu} / \mathrm{ml}$ for $C$. albicans and approximately $10^{2} \mathrm{cfu} / \mathrm{ml}$ for Aspergillus parasiticus (determination of the count was done by plating on Sabouraud Dextrose chloramphenicol Agar, Oxoid).

\section{Manufacture of ultrafiltered low- salt soft cheese}

Ultrafiltered milk was divided into two parts for conducting two independent experimental trials that were performed at separate times, the first was done to determine the sensory acceptability while the second one was carried out for determination of the viability of the fungal strains $C$. albicans \& Aspergillus parasiticus with different Nigella sativa oil concentrations in low-salt white soft cheese.

In the first experiment, Ultrafiltered milk was divided into five equal groups, from which four groups supplemented with $0.3,0.5,1.00$, and $3.00 \%(\mathrm{w} / \mathrm{w})$ of Nigella sativa oil while the $5^{\text {th }}$ one left as the control group. For soft cheese manufacture, all milk treatments were pasteurized at $80^{\circ} \mathrm{C}$ for 30 min, cooled and adjusted to $40^{\circ} \mathrm{C}$, then calcium chloride and sodium chloride were added at levels of $0.02 \%$, and $2 \%(\mathrm{w} / \mathrm{w})$, respectively, then NSO concentrations were added and renneted. Cheese samples were stored in plastic cups at $4^{\circ} \mathrm{C}$ for 21 days for physicochemical and sensory analysis at 0 -, 7-, 14-, and 21-days intervals. The physicochemical properties of the prepared cheeses were analyzed by titratable acidity, fat, moisture and total protein contents which were determined as described in (AOAC, 2005). Curd tension was measured according to the method used by (Shahein et al., 2014). While the sensory evaluation was determined using a nine-point hedonic scale as the method used by (Amini et al., 2019). Cheese samples were prepared and stored at $4^{\circ} \mathrm{C}$. The samples were evaluated by 15 panelists for appearance, taste, texture, smell, and overall acceptability.

In the second experiment, the ultrafiltered milk was divided into six equal groups instead of five in the first one, the first four groups were supplemented by Nigella sati$v a$ oil $(0.3,0.5,1.00$ and $3.00 \% \mathrm{w} / \mathrm{w})$ beside control positive and control negative groups. The manufacturing process was done typically as the first experiment then each group subdivided into 2 subgroups to inoculate one of them with C. albicans and the other one was inoculated with Aspergillus parasiticus before the Rennet was added. Cheese samples were stored in plastic cups at $4{ }^{\circ} \mathrm{C}$ for 21 days for microbiological analysis at $0,3,7,14$ and $21^{\text {st }}$ days intervals. The microbiological analysis of samples was done by stomaching ten grams of the inoculated prepared soft cheese samples with $90 \mathrm{ml}$ of $0.1 \%$ peptone water serially dilution for plating on duplicate plates of Sabouraud Dextrose chloramphenicol Agar (Oxoid). The plates were incubated aerobically at $25^{\circ} \mathrm{C}$ for 3-5 days for determining the count of the inoculated fungal strains.

\section{Statistical analysis}

Data were statistically analyzed using ANOVA variance analysis through the general linear model (GLM) procedure of the statistical analysis system software (SAS version 9.1, SAS Institute, Inc., 2003). The model included treatment, storage time, and their interaction as fixed effects. Differences between effects were assessed by the Duncan test $(\mathrm{P} \leq 0.05)$.

\section{Results and discussion}

\section{Compositional analysis of NSO}

The fatty acid profile of the used NSO was shown in Table 1, the level of unsaturated fatty acids was $84.33 \%$, while the level of saturated fatty acids was $15.67 \%$. The profile analysis of NSO by GC-MS indicated that the essential omega- 6 (Linoleic acid C18:2) was detected in a higher percentage $55.69 \%$, while oleic acid, linolenic acid, and palmitoleic acid were detected in levels, 27.92, 0.53, and $0.19 \%$ respectively. On the other hand, the saturated fatty acids were dominated by palmitic acid (C16:0) $12.19 \%$. NSO contained also the phytosterol, $\beta$-sitosterol 48.7 $\%$, stigmasterol $16.9 \%$, campesterol 12.6 $\%, \Delta 5$-avenasterol $12.1 \%, \Delta 7$-avenasterol 2 $\%$, cholesterol $0.8 \%$ and $\Delta 7$-stigmasterol $0.7 \%$. In addition, NSO had a higher level of polyphenols which was $3.8 \mathrm{~g} / \mathrm{kg}$.

The higher level of unsaturated fatty acids, high content of phenolics and phytosterols in NSO make it a functional ingredient with various health benefits, biological activities and enhancing the keeping quality of food applications (Hassanien et al., 2014). It was reported also that NSO has higher antioxidant activities due to its valuable content of polyphenols with redox potential (Bettaieb et al., 2010).

\section{Physicochemical properties of low- salt soft cheese supplemented with NSO}

The effect of adding Nigella sativa oil on the properties of low-salt soft cheese is

Table 1. Fatty acids, phytosterols and total phenolics of NSO.

Component Percentage

Fatty acids

Myristic acid (C14:0) $\quad 0.17$

Palmitic acid (C16:0) $\quad 12.19$

Palmitoleic acid (C16:1) $\quad 0.19$

Stearic acid (C18:0) $\quad 3.19$

Oleic acid (C18:1) $\quad 27.92$

Linoleic acid (C18:2) $\quad 55.69$

Linolenic acid (C18:3) $\quad 0.53$

Arachidic acid (C20:0) 0.12

$\Sigma$ Saturated fatty acids $\quad 15.67$

$\Sigma$ Unsaturated fatty acids $\quad 84.33$

Phytosterols

Cholesterol 0.8

Campesterol $\quad 12.6$

Stigmasterol $\quad 16.9$

B-Sitosterol $\quad 48.7$

$\Delta 5$-Avenasterol $\quad 12.1$

$\Delta 7$-Stigmasterol $\quad 0.7$

$\Delta$ 7-Avenasterol $\quad 2.00$

Total phenolics $\quad 3.8 \mathrm{~g} / \mathrm{kg}$ 
presented in Table 2. The highest moisture content $(69.70 \%)$ was recorded in control cheese while the lowest moisture content $(69.34 \%)$ in cheese samples with $3 \%$ NSO at zero time of storage. A slight decrease in moisture content between cheeses treatments was detected but it was significant at $p \leq 0.05$ which could be attributed to the effect of NSO on the dry matter content of cheese and replacement some of the cheese's moisture. A gradual decrease in moisture content was found during storage periods of all cheese treatments. The detectable loss of moisture in cheese samples was due to the evaporation and curd shrinkage because of the increase of acidity and the loss of whey from the cheese matrix. These results were in line with Cakir et al., (2016) who found that with the addition of NSO to Erzincan Tulum cheese the compositional analysis affected, and the moisture of cheese content decreased by the end of the storage period.

Titratable acidity of NSO treated cheese was higher than control samples and the acidity increased in all cheese samples during storage. Significant differences $(\mathrm{P} \leq 0.05)$ in acidity values were found between control and treated cheese. The acidity values were $0.37,0.39,0.41,0.62$ and $0.76 \%$ for control, T1, T2, T3 and T4 respectively at 21 days of storage. The development of acidity might be due to the fermentation of residual lactose and the acidity effect of Nigella sativa oil due to its fatty acid composition which interfere with acidity results. The results of fat $\%$ illustrated significant differences $(\mathrm{P} \leq 0.05)$ between all cheese samples. Fat increased gradually in all cheese samples during storage as a result of moisture loss in relation to the dry matter of cheese curd. At the end of storage period, higher fat values 15.57, 15.78, 16.47 , and $18.62 \%$ were recorded with $\mathrm{T} 1$, $\mathrm{T} 2, \mathrm{~T} 3$, and $\mathrm{T} 4$, respectively than control cheese. A positive correlation was found between oil concentration and fat percentages of examined cheese. There were no significant differences in protein content among cheese samples at the first week of storage, with a continuous increase in all cheese samples during storage due to the loss of water/total solids. These results were in accordance with Hassanien et al., (2014) ; Abd Elmontaleb et al., (2020). The curd tension and firmness of soft cheese were significantly $(\mathrm{P} \leq 0.05)$ decreased with the addition of NSO to cheese which might be due to oil interference in the cheese matrix and affecting casein diffusion.

\section{Sensory evaluation}

The sensory evaluation of the treated cheese with NSO was illustrated in Table 3. There were no significant differences $(\mathrm{P} \leq 0.05)$ in appearance between all cheese treatments. Nevertheless, during storage, little differences were noticed in the appearance of cheese samples. While the texture results were significantly higher $(\mathrm{P} \leq 0.05)$ in treated cheese samples than control by addition of NSO with a gradual improvement in texture of all cheese samples was observed until 14 days of storage. These results could be attributed to the softening effect of oil on the cheese texture and the effect of storage on the development of cheese texture by proteolysis, lipolysis, and hydrolysis of cheese matrix during storage. However, the texture values of T3 and T4 decreased especially at the end of the storage period which might be due to the over-concentration of NSO and more lipolysis occurred that changing of the cheese texture. Generally, there were clear differences between control and treated cheese samples in smell values. Higher smell values were reported in $\mathrm{T} 1$ and $\mathrm{T} 2$ supplemented with low concentrations of NSO than T3 and T4 of high oil concentrations. The smell of cheese samples with high-level content of NSO (1\%, $3 \%$ ) wasn't accepted by panelists throughout the storage period. The overall acceptability of cheese went to T1 $(0.3 \% \mathrm{NSO})$ and T2 $(0.5 \%$ NSO) with values 8.20 and 8.67 , respectively, at the end of storage time. Nearly similar results were detected by Halamova et al. (2010) and Hamid (2014) who observed improvement in the flavor of the examined cheese with addition of $0.1 \%$ and $0.3 \%$ of NSO respectively, while higher concentration levels could cause undesirable changes in color and flavor. likewise, Georgescu et al. (2018) found that the best ranges of Nigella sativa oil to

Table 2. Physicochemical properties of UF low-salt soft cheese during storage.

\begin{tabular}{|c|c|c|c|c|c|c|}
\hline Parameters & $\begin{array}{c}\text { Storage periods } \\
\text { (days) }\end{array}$ & Control & $\begin{array}{c}\mathrm{T} 1 \\
(0.3 \% \mathrm{NSO})\end{array}$ & $\begin{array}{c}\text { Treatments } \\
\text { T2 } \\
(0.5 \% \mathrm{NSO})\end{array}$ & $\begin{array}{c}\mathrm{T} 3 \\
(1.0 \% \mathrm{NSO})\end{array}$ & $\begin{array}{c}\mathrm{T} 4 \\
\text { (3.0\% NSO) }\end{array}$ \\
\hline Acidity\% & $\begin{array}{l}0 \\
7 \\
14 \\
21\end{array}$ & $\begin{array}{c}0.26 \mathrm{~m} \pm 0.01 \\
0.29 \mathrm{I} \pm 0.02 \\
0.31 \mathrm{jk} \pm 0.01 \\
0.37 \mathrm{~h} \pm 0.05\end{array}$ & $\begin{array}{l}0.30 \mathrm{kl} \pm 0.01 \\
0.31 \mathrm{jk} \pm 0.03 \\
0.33 \mathrm{ij} \pm 0.02 \\
0.39 \mathrm{~g} \pm 0.03\end{array}$ & $\begin{array}{c}0.31 \mathrm{jk} \pm 0.02 \\
0.34 \mathrm{i} \pm 0.03 \\
0.36 \mathrm{~h} \pm 0.05 \\
0.41 \mathrm{f} \pm 0.02\end{array}$ & $\begin{array}{l}0.40 \mathrm{fg} \pm 0.01 \\
0.46 \mathrm{e} \pm 0.02 \\
0.49 \mathrm{~d} \pm 0.04 \\
0.62 \mathrm{~b} \pm 0.02\end{array}$ & $\begin{array}{l}0.51 \mathrm{~d} \pm 0.01 \\
0.59 \mathrm{c} \pm 0.02 \\
0.63 \mathrm{~b} \pm 0.04 \\
0.76 \mathrm{a} \pm 0.01\end{array}$ \\
\hline Moisture\% & $\begin{array}{c}0 \\
7 \\
14 \\
21 \\
\end{array}$ & $\begin{array}{l}69.70 \mathrm{a} \pm 0.05 \\
68.47 \mathrm{e} \pm 0.06 \\
67.17 \mathrm{j} \pm 0.03 \\
65.97 \mathrm{n} \pm 0.02\end{array}$ & $\begin{array}{l}69.64 \mathrm{~b} \pm 0.05 \\
68.41 \mathrm{f} \pm 0.03 \\
67.05 \mathrm{k} \pm 0.04 \\
65.75 \mathrm{p} \pm 0.03\end{array}$ & $\begin{array}{c}69.51 \mathrm{l} \pm \pm 0.08 \\
68.31 \mathrm{~g} \pm 0.03 \\
66.71 \mathrm{l} \pm 0.02 \\
65.38 \mathrm{q} \pm 0.02\end{array}$ & $\begin{array}{c}69.48 \mathrm{c} \pm 0.03 \\
67.98 \mathrm{~h} \pm 0.02 \\
66.28 \mathrm{~m} \pm 0.04 \\
64.62 \mathrm{r} \pm 0.02\end{array}$ & $\begin{array}{c}69.34 \mathrm{~d} \pm 0.03 \\
67.74 \mathrm{i} \pm 0.02 \\
65.89 \mathrm{o} \pm 0.05 \\
63.99 \mathrm{~s} \pm 0.02\end{array}$ \\
\hline Fat $\%$ & $\begin{array}{c}0 \\
7 \\
14 \\
21\end{array}$ & $\begin{array}{c}14.70 \mathrm{~m} \pm 0.20 \\
14.88 \mathrm{I} \pm 0.10 \\
15.09 \mathrm{k} \pm 0.05 \\
15.26 \mathrm{ij} \pm 0.06\end{array}$ & $\begin{array}{c}14.97 \mathrm{l} \pm 0.06 \\
15.17 \mathrm{jk} \pm 0.06 \\
15.36 \mathrm{i} \pm 0.04 \\
15.57 \mathrm{~h} \pm 0.07\end{array}$ & $\begin{array}{c}15.13 \mathrm{k} \pm 0.06 \\
15.33 \mathrm{i} \pm 0.06 \\
15.56 \mathrm{~h} \pm 0.05 \\
15.78 \mathrm{~g} \pm 0.06\end{array}$ & $\begin{array}{l}15.67 \mathrm{~h} \pm 0.06 \\
16.07 \mathrm{f} \pm 0.07 \\
16.47 \mathrm{e} \pm 0.03 \\
16.57 \mathrm{e} \pm 0.05\end{array}$ & $\begin{array}{l}17.63 \mathrm{~d} \pm 0.06 \\
17.94 \mathrm{c} \pm 0.06 \\
18.33 \mathrm{~b} \pm 0.03 \\
18.62 \mathrm{a} \pm 0.04\end{array}$ \\
\hline Protein $\%$ & $\begin{array}{c}0 \\
7 \\
14 \\
21\end{array}$ & $\begin{array}{c}10.50 \mathrm{n} \pm 0.02 \\
10.61 \mathrm{kl} \pm 0.03 \\
10.77 \mathrm{hi} \pm 0.01 \\
10.92 \mathrm{f} \pm 0.02\end{array}$ & $\begin{array}{c}10.53 \mathrm{n} \pm 0.02 \\
10.64 \mathrm{jk} \pm 0.03 \\
10.81 \mathrm{gh} \pm 0.02 \\
10.97 \mathrm{de} \pm 0.01\end{array}$ & $\begin{array}{c}10.54 \mathrm{mn} \pm 0.02 \\
10.67 \mathrm{j} \pm 0.03 \\
10.83 \mathrm{~g} \pm 0.01 \\
11.01 \mathrm{~cd} \pm 0.02\end{array}$ & $\begin{array}{c}10.58 \mathrm{~lm} \pm 0.06 \\
10.75 \mathrm{i} \pm 0.02 \\
10.94 \mathrm{ef} \pm 0.02 \\
11.12 \mathrm{~b} \pm 0.03\end{array}$ & $\begin{array}{l}10.63 \mathrm{jk} \pm 0.04 \\
10.82 \mathrm{~g} \pm 0.04 \\
11.02 \mathrm{c} \pm 0.03 \\
11.23 \mathrm{a} \pm 0.02\end{array}$ \\
\hline Curd tension $\mathrm{mg} / 100 \mathrm{mg}$ & $\begin{array}{l}0 \\
7 \\
14 \\
21\end{array}$ & $\begin{array}{l}33.23 \mathrm{i} \pm 0.15 \\
34.31 \mathrm{c} \pm 0.09 \\
34.64 \mathrm{~b} \pm 0.07 \\
34.87 \mathrm{a} \pm 0.10\end{array}$ & $\begin{array}{l}33.12 \mathrm{j} \pm 0.11 \\
33.43 \mathrm{~g} \pm 0.08 \\
33.60 \mathrm{e} \pm 0.08 \\
33.83 \mathrm{~d} \pm 0.11\end{array}$ & $\begin{array}{c}32.93 \mathrm{k} \pm 0.12 \\
33.14 \mathrm{j} \pm 0.07 \\
33.34 \mathrm{~h} \pm 0.07 \\
33.52 \mathrm{f} \pm 0.12\end{array}$ & $\begin{array}{c}32.44 \mathrm{~m} \pm 0.11 \\
33.12 \mathrm{j} \pm 0.06 \\
33.25 \mathrm{i} \pm 0.06 \\
33.38 \mathrm{gh} \pm 0.11\end{array}$ & $\begin{array}{c}31.970 \pm 0.16 \\
32.20 \mathrm{n} \pm 0.05 \\
32.48 \mathrm{~m} \pm 0.05 \\
32.85 \mathrm{l} \pm 0.12\end{array}$ \\
\hline
\end{tabular}

*Data expressed as (mean $\pm \mathrm{SD})$ of three replicates. Means in the same column/row showing the same letters are not significantly different $(\mathrm{p} \leq 0.05)$. 
improve the sensory characteristics of soft cheese were 0.05 to $0.2 \% \mathrm{w} / \mathrm{w}$. Higher results were reported by Abd Elmontaleb et al. (2020) for the overall acceptability of Edam cheese with an additional higher level of NSO $(0.6 \%)$

\section{Microbiological analysis}

The antifungal effect of Nigella sativa oil on the survival of C. Albicans in different soft cheese treatments was represented in Table 4 that revealed, there were no significant reductions in the counts of $C$. Albicans in the first three days of storage within all cheese NSO treatments. However, the significant reduction in the count started at $7^{\text {th }}$ day of storage in (T2)
$0.5 \%$ of NSO $(3.95 \pm 0.43 \log 10 \mathrm{cfu} / \mathrm{g}),(\mathrm{T} 3)$ $1 \%$ of NSO $(3.89 \pm 0.29 \log 10 \mathrm{cfu} / \mathrm{g})$ and (T4) $3 \%$ of NSO $(2.90 \pm 0.27 \log 10 \mathrm{cfu} / \mathrm{g})$ treatments compared to control $(5.11 \pm 0.44$ $\log 10 \mathrm{cfu} / \mathrm{g})$. These reductions continued until the growth of C. Albicans couldn't be detected by end of the examination period $21^{\text {st }}$ day. There was a significant decrease in the count of $C$. Albicans in all cheese treatment groups at the $14^{\text {th }}$ and $21^{\text {st }}$ days of the storage period.

On the other hand, although the count of Aspergillus parasiticus showed the same pattern as $C$. albicans and didn't show a significant reduction in the counts in the first three days of examination in all cheese
NSO treatments, the count reduced significantly at $\mathrm{p} \leq 0.05$ in the $7^{\text {th }}$ day of examination in cheese treatments with $1 \%$ and $3 \%$ NSO compared to control and cheese treatments with $0.3 \%$ and $0.5 \%$ NSO. While the Aspergillus parasiticus couldn't grow on the $14^{\text {th }}$ and $21^{\text {st }}$ day of examination in all cheese treatments of NSO (Table 5).

It was observed that, although there are many co-factors helping in decreasing the count of Aspergillus parasiticus as refrigeration temperature and storage in strictly closed cups under anaerobic conditions. The combination of these factors with Nigella sativa oil accelerates reduction as well as prevention the growth of Aspergillus

Table 3. Sensory properties of UF low-salt soft cheese during storage.

\begin{tabular}{|c|c|c|c|c|c|c|}
\hline Parameters & $\begin{array}{l}\text { Storage periods } \\
\text { (days) }\end{array}$ & Control & $\begin{array}{c}\mathrm{T} 1 \\
(0.3 \% \mathrm{NSO})\end{array}$ & $\begin{array}{c}\text { Treatments } \\
\text { T2 } \\
(0.5 \% \mathrm{NSO})\end{array}$ & $\begin{array}{c}\mathrm{T} 3 \\
(1.0 \% \mathrm{NSO})\end{array}$ & $\begin{array}{c}\mathrm{T} 4 \\
(3.0 \% \mathrm{NSO})\end{array}$ \\
\hline Appearance & $\begin{array}{c}0 \\
7 \\
14 \\
21\end{array}$ & $\begin{array}{c}7.80 \mathrm{abc} \pm 0.41 \\
7.67 \mathrm{abcd} \pm 0.49 \\
7.47 \mathrm{bcd} \pm 0.52 \\
7.40 \mathrm{~cd} \pm 0.51\end{array}$ & $\begin{array}{c}7.87 \mathrm{ab} \pm 0.35 \\
7.80 \mathrm{abc} \pm 0.41 \\
7.73 \mathrm{abcd} \pm 0.46 \\
7.80 \mathrm{abc} \pm 0.41\end{array}$ & $\begin{array}{c}7.87 \mathrm{ab} \pm 0.35 \\
7.60 \mathrm{abcd} \pm 0.51 \\
7.60 \mathrm{abcd} \pm 0.51 \\
7.87 \mathrm{a} \pm 0.35\end{array}$ & $\begin{array}{c}7.60 \mathrm{abcd} \pm 0.51 \\
7.40 \mathrm{~cd} \pm 0.51 \\
7.47 \mathrm{bcd} \pm 0.52 \\
7.53 \mathrm{abcd} \pm 0.52\end{array}$ & $\begin{array}{c}7.33 \mathrm{~d} \pm 0.49 \\
7.33 \mathrm{~d} \pm 0.49 \\
7.40 \mathrm{~cd} \pm 0.51 \\
7.40 \mathrm{~cd} \pm 0.51\end{array}$ \\
\hline Texture & $\begin{array}{c}0 \\
7 \\
14 \\
21\end{array}$ & $\begin{array}{c}6.47 \mathrm{~h} \pm 0.52 \\
6.67 \mathrm{gh} \pm 0.49 \\
7.47 \mathrm{bcde} \pm 0.52 \\
7.53 \mathrm{bcde} \pm 0.52\end{array}$ & $\begin{array}{c}7.33 \mathrm{cde} \pm 0.49 \\
7.73 \mathrm{bc} \pm 0.46 \\
8.53 \mathrm{a} \pm 0.52 \\
8.40 \mathrm{a} \pm 0.63\end{array}$ & $\begin{array}{c}7.53 \mathrm{bcde} \pm 0.52 \\
7.80 \mathrm{~b} \pm 0.41 \\
8.53 \mathrm{a} \pm 0.52 \\
7.47 \mathrm{bcde} \pm 0.64\end{array}$ & $\begin{array}{c}7.40 \mathrm{bcde} \pm 0.51 \\
7.40 \mathrm{bcde} \pm 0.51 \\
7.67 \mathrm{bcd} \pm 0.49 \\
7.20 \mathrm{ef} \pm 0.56\end{array}$ & $\begin{array}{c}7.27 \mathrm{def} \pm 0.46 \\
7.20 \mathrm{ef} \pm 0.68 \\
7.13 \mathrm{ef} \pm 0.52 \\
6.87 \mathrm{fg} \pm 0.74\end{array}$ \\
\hline Smell & $\begin{array}{c}0 \\
7 \\
14 \\
21\end{array}$ & $\begin{array}{c}5.73 \mathrm{~h} \pm 0.46 \\
5.93 \mathrm{gh} \pm 0.46 \\
6.27 \mathrm{defg} \pm 0.46 \\
6.20 \mathrm{efgh} \pm 0.56\end{array}$ & $\begin{array}{c}6.67 \mathrm{cde} \pm 0.49 \\
7.07 \mathrm{bc} \pm 0.59 \\
8.07 \mathrm{a} \pm 0.88 \\
8.21 \mathrm{a} \pm 0.80\end{array}$ & $\begin{array}{c}6.60 \mathrm{cde} \pm 0.51 \\
7.33 \mathrm{~b} \pm 0.72 \\
8.33 \mathrm{a} \pm 0.62 \\
8.13 \mathrm{a} \pm 0.74\end{array}$ & $\begin{array}{c}6.47 \mathrm{def} \pm 0.52 \\
6.27 \mathrm{defg} \pm 0.46 \\
6.73 \mathrm{~cd} \pm 0.59 \\
7.07 \mathrm{bc} \pm 0.59\end{array}$ & $\begin{array}{c}5.87 \mathrm{gh} \pm 0.64 \\
5.80 \mathrm{gh} \pm 0.41 \\
6.00 \mathrm{fgh} \pm 0.53 \\
6.27 \mathrm{defg} \pm 0.70\end{array}$ \\
\hline Overall acceptability & $\begin{array}{c}0 \\
7 \\
14 \\
21\end{array}$ & $\begin{array}{l}6.40 \mathrm{~cd} \pm 0.51 \\
6.33 \mathrm{~cd} \pm 0.49 \\
5.67 \mathrm{ef} \pm 0.46 \\
5.27 \mathrm{fg} \pm 0.46\end{array}$ & $\begin{array}{l}7.07 \mathrm{~b} \pm 0.46 \\
8.20 \mathrm{a} \pm 0.77 \\
8.40 \mathrm{a} \pm 0.74 \\
8.20 \mathrm{a} \pm 0.68\end{array}$ & $\begin{array}{l}7.33 \mathrm{~b} \pm 0.49 \\
8.47 \mathrm{a} \pm 0.64 \\
8.47 \mathrm{a} \pm 0.64 \\
8.67 \mathrm{a} \pm 0.62\end{array}$ & $\begin{array}{c}6.53 \mathrm{c} \pm 0.52 \\
6.20 \mathrm{~cd} \pm 0.68 \\
7.27 \mathrm{~b} \pm 0.70 \\
6.13 \mathrm{cde} \pm 0.52\end{array}$ & $\begin{array}{c}6.13 \mathrm{cde} \pm 0.64 \\
5.93 \mathrm{de} \pm 0.70 \\
5.93 \mathrm{de} \pm 0.59 \\
5.07 \mathrm{~g} \pm 0.80\end{array}$ \\
\hline
\end{tabular}

Data expressed as (mean \pm SD) of three replicates. Means in the same column/row showing the same letters are not significantly different $(p \leq 0.05)$.

Table 4. Survival of candida albicans in different UF low-salt soft cheese treatments: $\left(\log _{10}\right.$ Mean \pm SE).

\begin{tabular}{lccccc} 
Storage days & 0 time & 3 days & 7 days & 14 days & 21 days \\
T1 $(0.3 \%$ of NSO) & $4.15 \pm 0.95 \mathrm{a}$ & $4.07 \pm 0.47 \mathrm{a}$ & $4.28 \pm 0.41 \mathrm{ad}$ & $3.19 \pm 0.33 \mathrm{a}$ & $2.48 \pm 0.11 \mathrm{a}$ \\
T2 $(0.5 \%$ of NSO) & $4.7 \pm 0.25 \mathrm{a}$ & $4.30 \pm 0.30 \mathrm{a}$ & $3.95 \pm 0.43 \mathrm{abc}$ & $3.28 \pm 0.30 \mathrm{a}$ & $2.90 \pm 0.28 \mathrm{a}$ \\
\hline T3 $(1 \%$ of NSO) & $4.09 \pm 0.23 \mathrm{a}$ & $4.17 \pm 0.62 \mathrm{a}$ & $3.89 \pm 0.29 \mathrm{abc}$ & $3.04 \pm 0.24 \mathrm{a}$ & No growth b \\
T4 $(3 \%$ of NSO) & $4.04 \pm 0.12 \mathrm{a}$ & $4.31 \pm 0.29 \mathrm{a}$ & $2.90 \pm 0.27 \mathrm{bc}$ & $3.18 \pm 0.10 \mathrm{a}$ & No growth b \\
\hline Control C + & $4.00 \pm 0.35 \mathrm{a}$ & $4.79 \pm 0.28 \mathrm{a}$ & $5.11 \pm 0.44 \mathrm{ad}$ & $3.40 \pm 0.16 \mathrm{~b}$ & $4.78 \pm 0.40 \mathrm{c}$ \\
\hline
\end{tabular}

Data expressed as (mean \pm SD) of three replicates. Means in the same column showing the same letters are not significantly different ( $\leq \leq 0.05$ ). Control $\mathrm{C}+$ : positive control of candida albicans ; Control A +: positive control of Aspergillus parasiticus.

Table 5. Survival of Aspergillus parasiticus in different UF low-salt soft cheese treatments: $\left(\log _{10} \mathrm{Mean} \pm \mathrm{SE}\right)$.

\begin{tabular}{|c|c|c|c|c|c|}
\hline Storage days & 0 time & 3 days & 7 days & 14 days & 21 days \\
\hline $\mathrm{T} 1(0.3 \%$ of NSO) & $2.48 \pm 0.21 \mathrm{a}$ & $2.60 \pm 0.25 \mathrm{a}$ & $2.30 \pm 0.24 \mathrm{a}$ & No growth a & No growth a \\
\hline T2 ( $0.5 \%$ of NSO) & $2.30 \pm 0.13 \mathrm{a}$ & $2.47 \pm 0.31 \mathrm{a}$ & $2.07 \pm 0.10 \mathrm{a}$ & No growth a & No growth a \\
\hline T3 (1\% of NSO) & $2.30 \pm 0.23 \mathrm{a}$ & $2.00 \pm 0.35 \mathrm{a}$ & $1.09 \pm 0.04 b$ & No growth a & No growth a \\
\hline T4 ( $3 \%$ of NSO) & $2.04 \pm 0.12 \mathrm{a}$ & $2.10 \pm 0.13 \mathrm{a}$ & $1.00 \pm 0.17 \mathrm{~b}$ & No growth a & No growth a \\
\hline Control A + & $2.48 \pm 0.35 \mathrm{a}$ & $2.60 \pm 0.15 \mathrm{a}$ & $2.30 \pm 0.20 \mathrm{ac}$ & $1.300 \pm 0.16 \mathrm{~b}$ & $1.86 \pm 0.40 \mathrm{~b}$ \\
\hline
\end{tabular}

Data expressed as (mean \pm SD) of three replicates. Means in the same column showing the same letters are not significantly different ( $\leq \leq 0.05$ ). Control $\mathrm{C}+$ : positive control of candida albicans, Control A +: positive control of Aspergillus parasiticus 
parasiticus starting from the low concentration oil $(0.3 \%)$ at day $14^{\text {th }}$ of the storage period which indicates that the addition of oil improves the quality of white soft cheese and increase its shelf life. In general, the antifungal activities of back seed oil against different types of pathogenic fungi were attributed in several studies to the presence of $\beta$-sitosterol, stigmastero, oleic acid, and long-chain fatty acids (Gupta et al., 2012; Asdadi et al., 2014). Nigella sativa oil has a moderate efficacy against Candida species (Halamova et al., 2010; Taha et al., 2010; Shokri, 2016). other results reported by Khosravi et al., (2011) suggested using Nigella sativa oil as natural inhibitors in foods at low levels to protect food from fungal and toxin contaminations by Aspergillus parasiticus. However, Maraqa et al., (2007) and El-Nagerabi et al., (2012) reported that a higher concentration of NSO (3\%) was the most effective level to cause complete inhibition of aflatoxin B1 produced by Aspergillus parasiticus.

\section{Conclusions}

Nigella sativa oil could be used in food as a promising natural preservative enhancing the shelf life of the cheeses. Supplementation of low salt soft cheese with NSO $(0.5 \% \mathrm{w} / \mathrm{w})$ is the most effective oil concentration in this study that kept considerable physicochemical and sensorial properties of cheese. In addition, it significantly reduced the counts of the examined fungal strains ( $C$. albicans and Aspergillus parasiticus) by 1.4 and $2.30 \operatorname{logs} \mathrm{cfu} / \mathrm{g}$, respectively after 14 days of storage.

\section{References}

Abd Elmontaleb H, Galal E, Abdelmageed D, Hamdy S, 2020. Biochemical and microbiological properties of Edam cheese with black cumin oil. EJFS 0: 00. doi:10.21608/ejfs.2020.26081.1046

Amini R, Islam M, Kitamura Y, Kokawa M, 2019. Utilization of Fermented Rice Milk as a Novel Coagulant for Development of Paneer (Soft Cheese). Foods 8:339.

AOAC, 2005. Official Methods of Analysis 18th Edition. Pub AOAC International Maryland.

Asdadi A, Harhar H, Gharby S, Bouzoubaâ Z, Yadini A, Moutaj R, Hadek ME, Chebli B, Hassani LM, 2014. Chemical Composition and Antifungal Activity of Nigella Sativa Oil Seed Cultivated In Morocco. Int J Pharm Sci Invent 3:0915.
Bettaieb I, Bourgou S, Wannes WA, Hamrouni I, Limam F, Marzouk B, 2010. Essential Oils, Phenolics, and Antioxidant Activities of Different Parts of Cumin (Cuminum cyminum L.). J Agric Food Chem 58:10410-8.

Çakır Y, Çakmakçı S, 2018. Some microbiological, physicochemical, and ripening properties of Erzincan Tulum cheese produced with added black cumin (Nigella sativa L.). J Food Sci Technol 55:1435-43.

Cakir Y, Cakmakci S, Hayaloglu AA, 2016. The effect of addition of black cumin (Nigella sativa L.) and ripening period on proteolysis, sensory properties, and volatile profiles of Erzincan Tulum (Şavak) cheese made from raw Akkaraman sheep's milk. Small Ruminant Res 134:65-73.

El-Nagerabi SAF, Al-Bahry SN, Elshafie AE, AlHilali S., 2012. Effect of Hibiscus sabdariffa extract and Nigella sativa oil on the growth and aflatoxin B1 production of Aspergillus flavus and Aspergillus parasiticus strains. Food Control, 25:59-63.

Georgescu M, Tăpăloagă PR, Tăpăloagă D, Furnaris F, Ginghină O, Negrei C, Giuglea C, Bălălău C, Ștefănescu E, Popescu IA, Georgescu D, 2018. Evaluation of antimicrobial potential of Nigella sativa oil in a model food matrix. Farmacia 66:1028-36.

Georgescu M, Raita Ștefania M, Tăpăloagă D, 2019. Total nitrogen, water-soluble nitrogen and free amino acids profile during ripening of soft cheese enriched with Nigella sativa seed oil. The Euro Biotech J 3:90-6.

Goñi P, López P, Sánchez C, Gómez-Lus R, Becerril R, Nerín C, 2009. Antimicrobial activity in the vapour phase of a combination of cinnamon and clove essential oils. Food Chem 116:982-989.

Gupta S, Satishkumar M, Duraiswamy B, Das S, Chhajed M, 2012. Potential herbs and its phytoconstituents against fungal infection: A systematic review. World J Pharm Res 1:1-20.

Halamova K, Kokoska L, Flesar J, Sklenickova O, Svobodova B, Marsik P, 2010. In Vitro Antifungal Effect of Black Cumin Seed Quinones against Dairy Spoilage Yeasts at Different Acidity Levels. J Food Prot 73:22912295.

Hassanien MFR, Mahgoub SA, El-Zahar KM, 2014. Soft cheese supplemented with black cumin oil: Impact on food borne pathogens and quality during storage. Saudi J Biol Sci 21:280-288.

Hosseinzadeh H, Parvardeh S, Asl MN,
Sadeghnia HR, Ziaee T, 2007. Effect of thymoquinone and Nigella sativa seeds oil on lipid peroxidation level during global cerebral ischemia-reperfusion injury in rat hippocampus. Phytomedicine 14:621-627.

Hamid A, 2014. Effect of cumin oil concentrations on chemical composition and sensory characteristics of Sudanese white cheese during ripening. Int J Curr Microbiol Appl Sci 3:961-968.

Kahsai AW, 2002. Isolation and Characterization of Active Ingredients from Nigella Sativa for Antibacterial Screening. Electronic Theses and Dissertations. Paper 692. https://dc.etsu.edu/etd/692

Khorshidian N, Yousefi M, Khanniri E, Mortazavian AM, 2018. Potential application of essential oils as antimicrobial preservatives in cheese. IFSET 45:6272.

Khosravi A, Minooeianhaghighi M, Shokri H, Emami S, Alavi S, Asili J, 2011. The potential inhibitory effect of cuminum cyminum, ziziphora clinopodioides and nigella sativa essential oils on the growth of Aspergillus fumigatus and Aspergillus flavus. Braz J.Microbiol 42:216-224.

Kostadinović LM, Popović SJ, Puvača NM, Čabarkapa IS, Kormanjoš ŠM, Lević JD, 2016. Influence of Artemisia absinthium essential oil on antioxidative system of broilers experimentally infected with Eimeria oocysts. Veterinarski arhiv 86:253-264.

Maraqa A, Al-Sharo'a NF, Farah H, Elbjeirami WM, Shakya A, Sallal A, 2007. Effect of Nigella sativa Extract and Oil on Aflatoxin Production by Aspergillus flavus. Turk J Biol 31:155159.

Oliveira RBA, Margalho LP, Nascimento JS, Costa LEO, Portela JB, Cruz AG, Sant'Ana AS, 2016. Processed cheese contamination by spore-forming bacteria: A review of sources, routes, fate during processing and control. Trends Food Sci Technol 57:11-19.

Puvača N, 2018. Bioactive compounds in selected hot spices and medicinal plants. J Eng Technol Manag 1:8-17.

Puvača N, Pelić D, Tomić V, Radišić R, Milanović S, Soleša D, Budakov D, Cara M, Bursić V, Petrović A, 2020. Antimicrobial efficiency of medicinal plants and their influence on cheeses quality. Mljekarstvo, 70:3-12.

Samadan MF, Kinni SG, Seshagiri M, Mörsel J-T, 2010. Fat-Soluble Bioactives, Fatty Acid Profile and Radical Scavenging Activity of Semecarpus anacardium Seed Oil. 
JAOCS 87:885-894.

Shahein MR, Hassanein A, Zayan A, 2014.

Evaluation of soft cheese manufactured from camel and buffalo milk. WJDFS 9:213-219.

Shokri H, 2016. A review on the inhibitory potential of Nigella sativa against pathogenic and toxigenic fungi. AJP 6:2133.
Taha M, Azeiz A, Saudi W, 2010. Antifungal effect of thymol, thymoquinone and thymohydroquinone against yeasts, dermatophytes and nondermatophyte molds isolated from skin and nails fungal infections. EJB, 28.

Tehrani F, Sadeghi E, 2015. Effect of mint essential oil on growth of Listeria monocytogenes during the ripening and storage of Iranian white brined cheese. JAEBS 5:150-154.

Trmčić, A, Ralyea, R, Meunier-Goddik, L, Donnelly, C, Glass, K, D'amico, D, Wiedmann, M, 2017. Consensus categorization of cheese based on water activity and $\mathrm{pH}-\mathrm{A}$ rational approach to systemizing cheese diversity. J Dairy Sci 100:841-847. 